\title{
ANTIMICROBIAL AND TOXICOLOGICAL STUDIES OF RICINODENDRON HEUDELOTII (BAILL.)
}

\section{OMOLARA FAITH YAKUBU ${ }^{1}$, ABIODUN HUMPHREY ADEBAYO ${ }^{1 *}$, TOLULOPE OLUWASOMO FAMAKINWA ${ }^{1,2}$, OLUWATOBI SAMUEL ADEGBITE ${ }^{3}$, TEMITOPE ARIKE ISHOLA ${ }^{1}$, LORETTA ONOSHOWNEN IMONIKHE ${ }^{1}$, OLADIPUPO ALABA ADEYEMI ${ }^{1}$, OLUFISAYO ADEBOLA AWOTOYE ${ }^{1}$ AND EMEKA EZE JOSHUA IWEALA $^{1}$}

${ }^{1}$ Department of Biochemistry, College of Science and Technology, Covenant University, PMB 1023, Canaan land, Ota, Ogun, Nigeria ${ }^{2}$ Department of Biological Sciences, Baze University, Abuja, FCT, Nigeria. ${ }^{3}$ Department of Chemical Science, Osun State University, Osun State, Nigeria. Email: abiodun.adebayo@covenantuniversity.edu.ng

Received: 13 July 2017, Revised and Accepted: 16 October 2017

\section{ABSTRACT}

Objective: This work assessed the antimicrobial activity and toxicological consequence of the ethanolic extract of Ricinodendron heudelotii (Baill).

Methods: The antimicrobial potential of the leaf extract was investigated against 9 different microorganisms using the agar well diffusion method while the minimum inhibitory concentration (MIC) was ascertained. Toxicity evaluations were carried out on five groups of seven albino rats each for 28 days. Rats in Group A received normal saline, while those in Groups B, C, D, and E received 250, 500, 1000, and 2000 mg/kg body weight (b.w.) of the extract. After treatment, they were anesthetized, blood samples collected for biochemical assays; organs isolated, weighed, and processed for histopathological studies.

Results: The phytochemical screening showed the presence of glycosides, tannins, polyphenols, terpenoids, and alkaloids while saponin was absent. Antimicrobial effect was observed against 7 of the 9 microorganisms tested with inhibition zone and MIC ranging from 18 to 36 mm and 31.25 to $62.5 \mathrm{mg} / \mathrm{mL}$, respectively. Liver function tests were significantly $(\mathrm{p}<0.05)$ increased, whereas no significant change in total protein and creatinine levels was observed. Histology showed a sinusoidal congestion and vacuolar degeneration of hepatocytes in groups administered higher doses, and a dose-dependent reduction was observed in some hematological parameters.

Conclusion: The results obtained suggest that the $R$. heudelotii may not induce significant toxic effect below $3600 \mathrm{mg} / \mathrm{kg}$ b.w. and could serve as an effective antibiotic.

Keywords: Ricinodendron heudelotii, Euphorbiaceae, Antimicrobial, Toxicology, Histology.

(c) 2018 The Authors. Published by Innovare Academic Sciences Pvt Ltd. This is an open access article under the CC BY license (http://creativecommons. org/licenses/by/4. 0/) DOI: http://dx.doi.org/10.22159/ajpcr.2018.v11i1.21251

\section{INTRODUCTION}

Herbal plants, known to contain countless biologically active compounds [1], have been utilized for the management and cure of various ailments throughout human history. Above $50 \%$ of all contemporary drugs are from natural products, which play a significant role in drug evolution programs [2]. Nature has been the origin of healing agents over the years. Medicinal plants, for many centuries and today, have been used for curing different types of diseases in virtually all cultures [3]. Ricinodendron heudelotii (Baill.) is a member of the Euphorbiaceae family. It is a rapid-growing secondary forest tree native to West and Central Africa [4]. It is traditionally called "Njansang" in Cameroun and "Okwe" in South East Nigeria [5]. $R$. heudelotii has been used in folk tradition for treating cough, yellow fever, anemia, malaria, stomach pain, and intestinal disease and used as a poison neutralizer [6,7]. A blend of the bark of $R$. heudelotii has been reported to stimulate sexual desires and increase passing out of urine in some parts of Cameroon [6]. Bark extracts are also used to prevent abortion $[8,9]$. Its leaves are used to treat looseness of the bowels while the fruits are used as seasoning [7]. It is cultivated by farmers for topsoil fertility advancement, light wood work, shades, and pasturage [10]. The seed is often used as a thickener in soup making [5]. The seeds have been reported to contain hydrogen cyanide, tannin, alkaloid, phenol, saponin, and flavonoid [5]. The effectiveness of existing antibiotics has been challenged by the advent of drug-resistant pathogens, thus making antibiotic resistance to be a global concern [11]. Thus, in view of the fact that adequate scientific information regarding the use of the plant is lacking, this makes preclinical toxicological and therapeutic studies important. This study is therefore focused on exploring the biochemical, antimicrobial, histological, and hematological effects of $R$. heudelotii in rats.

\section{METHODS}

\section{Plant material}

The leaves were collected on October 2015 in Covenant University Ota, Ogun, Nigeria, and certified by Dr. J.O. Popoola of the Department of Biological Sciences, Covenant University, Ota, Nigeria. Sample of the leaf was deposited herbarium section of the Forest Research Institute of Nigeria with voucher no FHI 110573. Leaves were dried at room temperature $\left(25^{\circ} \mathrm{C}\right)$ and grinded using an electric blender into coarse powder. These powdered samples were sealed in plastic bowls until needed for the study.

\section{Microorganisms}

The selected bacterial strains for the current study were Klebsiella pneumoniae, Pseudomonas aureginosa, Shigella sp., Escherichia coli (Gram-negatives), Staphylococcus aureus, Bacillus sp., Micrococcus sp., Streptococcus faecalis, and Salmonella sp. (Gram-positive) while the fungal strain was Candida albicans. They were all obtained from culture collection center, Department of Biological Sciences, Covenant University, Ota. All organisms were sustained on nutrient broth (NB) at $37^{\circ} \mathrm{C}$ and fungus on potato dextrose agar (PDA) at a temperature of $28^{\circ} \mathrm{C}$.

Experimental animals and housing

In this study, 35 male adult albino Wistar rats having weight between 170 and $200 \mathrm{~g}$ were purchased from Lagos University Teaching Hospital, 
Lagos, Nigeria, and kept at a maintained temperature and fed with rat chow (Graceline Feeds Ota, Ogun State) along with water. The rats were permitted to adapt to the environment for 2 weeks before the inception of the experiment. This study was approved by the Biological Sciences Research Ethics Committee, Covenant University. All experimental rats were managed in adherence to the rules of the National Institute of Health for the use and care of laboratory animals [12]

\section{Extraction and phytochemical screening of the plant}

The powdered leaf samples (580 g) were extracted by maceration with $3 \mathrm{~L}$ of $95 \%$ ethanol (Sigma-Aldrich) and kept at room temperature for 3 days. The solution was stirred daily for thorough mixing and sieved thereafter to obtain the filtrate which was further condensed at reduced temperature of $40^{\circ} \mathrm{C}$ and pressure through a rotary evaporator [13]. The yield of the plant extract obtained was $13.8 \%$.

The ethanolic extract was exposed to preliminary phytochemical tests to ascertain the specific phytoconstituents contained in the leaf such as tannins, alkaloids, glycosides, steroids, flavonoids, terpenoids, saponnins, anthocyanin, and phenols. Such tests were determined by the typical color change following guidelines as described by Harborn [14] and Sofowora [15].

\section{Antimicrobial studies of plant extract}

The antimicrobial effect of ethanolic extract of $R$. heudelotii was carried out using agar diffusion method described by Benkeblia [16] with slight modifications. Bacterial cell suspensions of about 18-24 h were adjusted to a $0.5 \mathrm{McF}$ arland standard. Mueller-Hinton agar plates were seeded with $100 \mu \mathrm{L}$ of each of the bacterial cell suspensions, and wells were bored using $0.8 \mathrm{~mm}$ diameter cork borer. The extract was dissolved in dimethyl sulfoxide and aseptically introduced into the bored wells, allowed to spread out, and incubated at $37^{\circ} \mathrm{C}$ for $18-24 \mathrm{~h}$ for bacteria, and thereafter, the diameter of the inhibition zones were measured. The same method was employed for fungal isolate which was initially cultured on PDA and incubated at room temperature for 48 h. For standard, standard antibiotic discs of $6 \mathrm{~mm}$ diameter (Hi-Media) for gentamicin were used.

Minimum inhibitory concentration (MIC) was determined by preparing different concentrations of the extracts using sterile distilled water. Standardized bacterial suspension $(0.1 \mathrm{~mL})$ was introduced into test tubes containing nutrient broth, and different concentrations of the extract were introduced to them after which they were aerobically incubated at $37^{\circ} \mathrm{C}$ for $18-24 \mathrm{~h}$. The highest dilution where there was no bacterial (or fungal) growth was recorded as the MIC.

\section{Acute toxicity}

Lethal dose $\left(\mathrm{LD}_{50}\right)$ was determined using the method as described by Lorke [17]. This involves two stages. At the initial stage, rats were grouped into 3 , each containing 3 rats and received the ethanolic extract of $R$. heudelotii at an oral dose of 10,100 , and $1000 \mathrm{mg} / \mathrm{kg}$ body weight (b.w.), respectively. For the second stage, different doses of 2900, 3600, and $5000 \mathrm{mg} / \mathrm{kg}$ b.w. were administered to another set of 3 groups of three rats. The rats were monitored over $72 \mathrm{~h}$ and 2 weeks period for morbidity or mortality; changes in behavior were recorded.

\section{Experimental design}

A total of 35 rats were purchased and equally distributed across five experimental groups. Group I rats was administered $1 \mathrm{ml}$ of distilled water while Groups II-IV were given orally 250, 500, 1000, and $2000 \mathrm{mg} / \mathrm{kg}$ b.w. of the extract, respectively, for 28 days. At the end of the 28-day treatment, food was withdrawn from the animals overnight, and the following morning, they were anesthetized in diethyl ether. They were afterward dissected from the abdomen; blood samples were obtained through the cardiac puncture into heparinized tubes. Plasma was obtained by centrifuging at $3000 \mathrm{rpm}$ for $15 \mathrm{~min}$ [18] and kept at $-20^{\circ} \mathrm{C}$ inside Eppendorf tubes until needed for biochemical assays. The organs (liver and kidney) obtained were used for histological examination.

\section{Biochemical assay}

The commercial test kits for liver function test were purchased from Randox Laboratory, United Kingdom. Standard procedures were used to evaluate the protein concentration [19], aspartate aminotransferase (AST) [20], alkaline phosphatase (ALP) [21], alanine aminotransferase (ALT) [22], cholesterol [23], total albumin [24], total bilirubin [25], urea [26], and creatinine [27].

\section{Hematological assays}

Hematological parameters were estimated with the aid of an automated hematology system analyzer, mean cell volume, white blood cell count, hemoglobin, red blood cell count, hematocrit (HCT), platelet count (PLT), mean cell hemoglobin (MCH), mean corpuscular hemoglobin concentration, percentage lymphocyte, and percentage granulocyte [28].

\section{Histopathological studies}

The method according to Aliyu et al. [29] was adopted. The organ tissues were fixed in normal saline for $72 \mathrm{~h}$ and cut into thin slices $2.1 \mathrm{~mm}$ thick. The tissues were dehumidified using liquor. They were thereafter treated with paraffin wax and cast into blocks; tissue sections were then slit into $5 \mu \mathrm{m}$ using microtome and allowed to dry on a slide. The slides were afterward soiled with hematoxylin-eosin stain, analyzed using a light microscope, and photomicrographs recorded [29,30]

\section{Statistical analysis}

Data were analyzed through one-way analysis of variance (ANOVA) and Tukey's test using the statistical package for the social sciences (SPSS), version 21.0 (SPSS Inc., Chigaco, IL, USA). Probability of * $\mathrm{p}<0.05$ was considered to be statistically significant. All data were represented as mean \pm standard error mean for 7 animals graphically using Graph pad prism, version 5.0 .

\section{RESULTS}

\section{Phytochemical analysis}

The qualitative phytochemical analysis revealed the existence of tannins, flavonoids, alkaloids, cardiac glycosides, saponins, steroids, and terpenoids in the leaf extract (Table 1).

\section{Acute toxicity}

Administration of varying concentrations of ethanolic extract of $R$. heudelotii at doses 10, 100, 1000, and $2900 \mathrm{mg} / \mathrm{kg}$ did not cause any changes in behavior. However, there were behavioral changes in the group administered 3600 and $5000 \mathrm{mg} / \mathrm{kg}$ b.w. of the extract; decreased locomotive activity, food intake, weight loss, and weakness were observed in these groups. No mortality of rats was experienced all through the period of administration.

\section{Effects of $\boldsymbol{R}$. heudelotii extract on biochemical parameters}

The ethanolic extract showed a significant increase $(\mathrm{p}<0.05)$ in the activity of ALT and AST (Fig. 1). Similarly, the levels of urea were significantly $(\mathrm{p}<0.05)$ elevated (Fig. 2) in Groups II, III, and IV. The activity of ALP significantly increased $(\mathrm{p}<0.05)$ in the group treated with $2000 \mathrm{mg} / \mathrm{kg}$ b.w. of leaf extract. Total protein levels were significantly decreased (Fig. 1), while creatinine levels were unaltered (Fig. 2) across all the treated groups.

\section{Table 1: Qualitative phytochemical screening of $R$. heudelotii}

\begin{tabular}{ll}
\hline Phytochemicals & Status \\
\hline Phenols & Absent \\
Flavonoids & Present \\
Terpenoids & Present \\
Cardiac glycosides & Present \\
Alkaloids & Present \\
Tannins & Present \\
Steroids & Present \\
Saponins & Present \\
Anthocyanin & Absent \\
\hline
\end{tabular}


Histopathological studies

Compared with the control groups, no remarkable alterations were noticed in the morphology of the organ tissues of rat administered $250 \mathrm{mg} / \mathrm{kg}$ b.w. However, noticeable cellular alterations such as severe portal and central venous congestion were observed in the liver organ of rats administered $500 \mathrm{mg} / \mathrm{kg} \mathrm{b.w}$. of the extract including severe periportal cellular infiltration and vacuolar degeneration of hepatocytes of those given 1000 and 2000 $\mathrm{mg} / \mathrm{kg}$ b.w. (Fig. 3). The kidney of rats treated with $1000 \mathrm{mg} / \mathrm{kg}$ b.w. of extract showed a mild tubular degeneration (long arrow Fig. 4) with interstitial hemorrhage (short arrows Fig. 4) at the renal cortex, while the $2000 \mathrm{mg} / \mathrm{kg}$ b.w. group showed mild-to-moderate interstitial hemorrhage (Fig. 4).

\section{DISCUSSION}

Toxicological evaluations are essential in determining the safety limit of plant extracts and herbs in animals. These are usually conducted to determine the safety of the plant extract in humans. In this study, no death occurred all through the treatment period. There were neither occurrences of diarrhea nor changes in locomotor activity observed. From the preliminary qualitative phytochemical test carried out on the ethanolic leaf extract, tannins, steroids, terpenoids, flavonoids, saponin, cardiac glycosides, and alkaloids were discovered present (Table 1). These secondary metabolites contribute significantly to biological activities of medicinal plants as some of them have shown excellent antimicrobial, antioxidant, and antimalarial properties. Tannins have

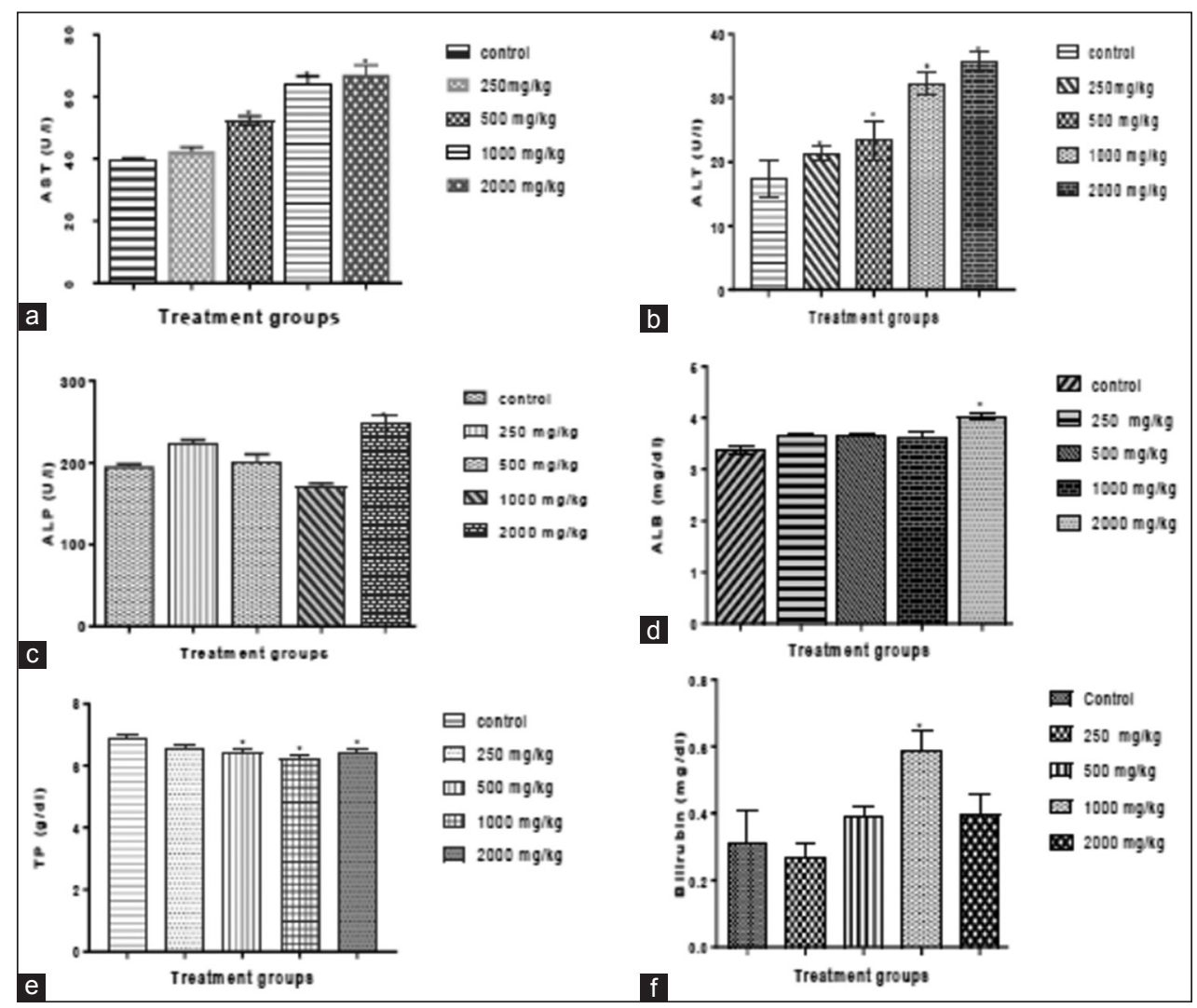

Fig. 1: Effect of Ricinodendron heudelotii extract on liver function parameters in albino Wistar rats. (a) AST: Aspartate aminotransferase; (b) ALT: Alanine amino transferase; (c) ALP: Alkaline phosphatase; (d) ALB: Albumin; (e) TP: Total protein; (f) BIL: Bilirubin. Values are presented as mean \pm standard error of mean of 7 replicates; *significant at $p<0.05$ as compared with control

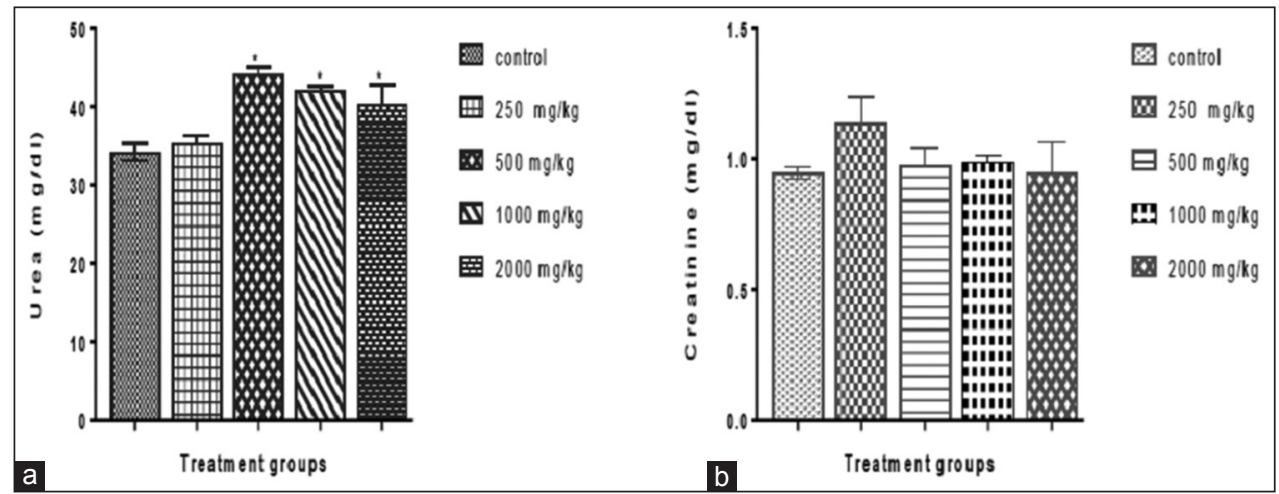

Fig. 2: Effect of Ricinodendron heudelotii extract on. (a) Urea and (b) creatinine levels. Values are presented as mean \pm standard error of mean of 7 replicates; ${ }^{*} \mathbf{p}<0.05$ as compared with control 


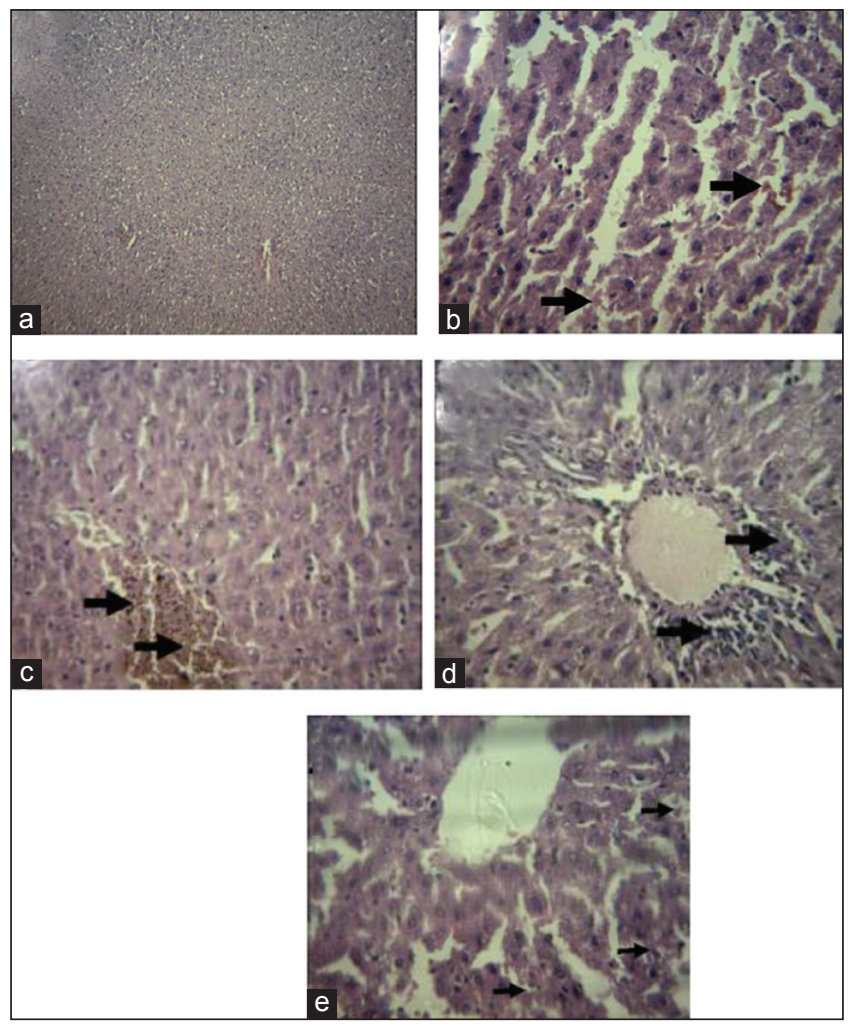

Fig. 3: Photomicrograph of liver tissues $(\mathrm{H}$ and $\mathrm{E}, \times 400)$ of rats (a) with normal features in the control group, (b) treated with $250 \mathrm{mg} / \mathrm{kg}$, (c) treated with $500 \mathrm{mg} / \mathrm{kg}$, (d) treated with $1000 \mathrm{mg} / \mathrm{kg}$, (e) treated with $2000 \mathrm{mg} / \mathrm{kg}$ body weight of the extract of Ricinodendron heudelotii

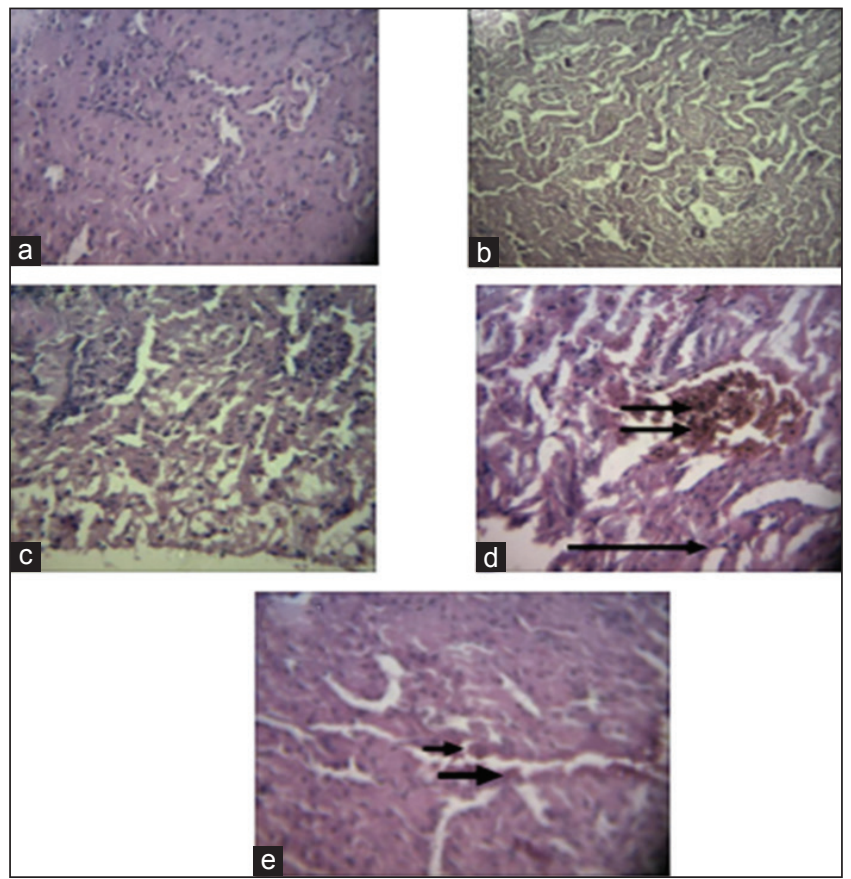

Fig. 4: Photomicrograph of kidney tissues $(\mathrm{H}$ and $\mathrm{E}, \times 400)$ of rats, (a) with normal features in the control group, (b) treated with $250 \mathrm{mg} / \mathrm{kg}$, (c) treated with $500 \mathrm{mg} / \mathrm{kg}$, (d) treated with $1000 \mathrm{mg} / \mathrm{kg}$, (e) treated with $2000 \mathrm{mg} / \mathrm{kg}$ body weight of the extract of Ricinodendron heudelotii

amazing stringent properties. They are known to hasten the healing of wounds [31], treat bacterial infections, and dysentery [32]. Flavonoids have also been reported to be efficient reactive oxygen species scavengers as their anticancer property ascertained on their chelating and antioxidant attributes [33].
The antimicrobial potential of the leaf extract may be hard to correlate to a specific compound as a result of their complexity [34]; however, tannins have been reported by Hatano et al. [35] to strongly inhibit microorganisms, especially effect on S. aureus. This is in line with this present study where the leaf extract showed a zone of inhibition of 


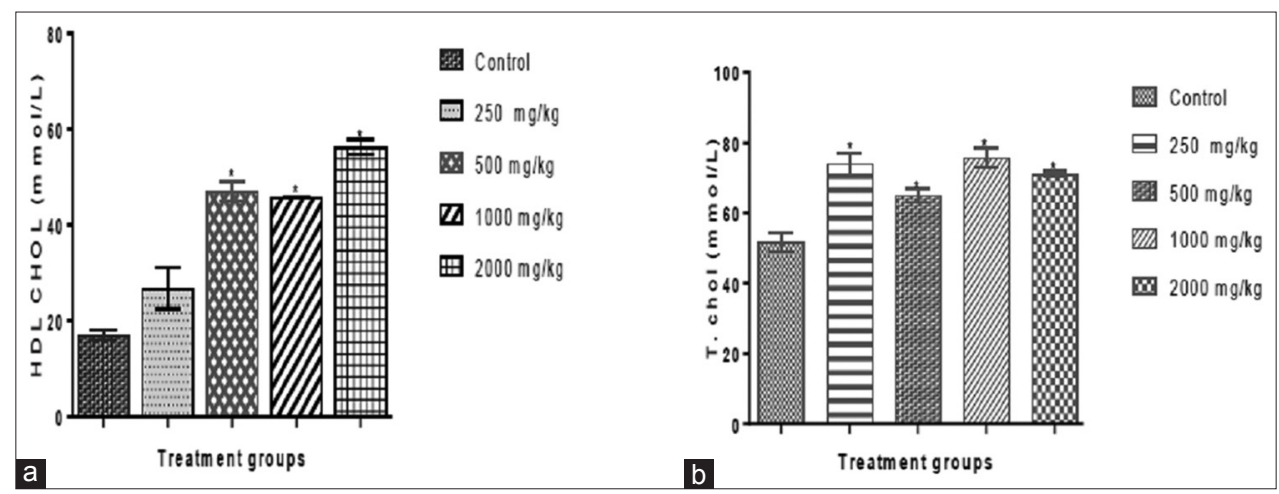

Fig. 5: Effect of Ricinodendron heudelotii extract on. (a) High density lipoprotein and (b) total cholesterol. Values are represented as mean \pm standard error of mean of 7 replicates; * $\mathbf{p}<0.05$ as compared with control

$36 \mathrm{~mm}$ against the organism (Table 4). The class of tannin that possesses antibiotic property is the ellagitannins which was also reported by Hatano et al. [35]. Our findings revealed that the ethanolic leaf extract of $R$. heudelotii showed activity against most of the microorganism tested (Table 2). Three of the organisms, Klebsiella pneumoniae, Candida albicans, and Salmonella sp were, however, resistant to the extract. This is in accordance with Oyono et al. [36] where they observed resistance of these strains to the bark extract of $R$. heudelotii. The diameter of zone of inhibition varied from 15 to $30 \mathrm{~mm}$ and 18 to $36 \mathrm{~mm}$ for gentamycin and the extracts, respectively (Table 2 ). The disparity observed can be linked to either the variation of active ingredients available in it or the mode of action on Gram-negative and Gram-positive bacteria [36]. The MIC for E. coli and Streptococcus faecalis was $31.25 \mathrm{mg}$ while that of Bacillus species, $S$. aureus, Shigella species, and Micrococcus species was $62.5 \mathrm{mg}$ (Table 3), this implies that small doses can be effective against microorganisms.

Mean $\mathrm{LD}_{50}$ value is often used as the basis for assessing acute toxicity [19]. Our study has shown that ethanolic leaf extract $R$. heudelotii could produce signs of toxicity at very high concentrations (3600 and $5000 \mathrm{mg} / \mathrm{kg} \mathrm{b.w}$.) but not death. This shows that the extract is relatively safe or may be slightly toxic just like any xenobiotics since it falls within the range of 1000-5000 mg/kg b.w. [37]. No significant difference $(\mathrm{p}<0.05)$ in the weight of the animals was observed. However, the organ weights in the $2000 \mathrm{mg} / \mathrm{kg}$ b.w. group showed a significant difference (Table 4), this may be as a result of the enhanced working ability of the organs [38].

Hematological parameters are useful markers used to ascertain the adverse effect of plant extracts or even drugs on blood constituents [39]. In this study, treatment with the plant extract led to a significant decrease $(\mathrm{p}<0.05)$ in PLTs in rats in the $2000 \mathrm{mg} / \mathrm{kg}$ b.w. group (Table 5). According to McLellan et al. [40], reduction in PLT in experimental rats indicates detrimental action on the blood's oxygen transporting ability as well as thrombopoietin. The observed reduction in the PLTs in this study indicates that RH extract may cause disorder in the blood oxygen transporting ability. Reductions in red blood cell (RBC) and HCT were also observed (Table 5). Reduction in RBC was statistically significant in the group treated with $2000 \mathrm{mg} / \mathrm{kg}$ b.w. of $R$. heudelotii extract while the reduction in HCT was dose dependent but not significant. This could be as a result of osmoregulatory system disturbance of the blood cells or impairment of the cell membrane. The observed reduction in hematological indices could indicate erythrocyte destruction [41]. Therefore, the reduction observed in RBC count and HCT may be linked to delayed hemopoeisis, shrinkage, and destruction of RBC. Likewise, the oxygen-transporting ability of the blood and the oxygen supplied to the tissues may be disrupted following administration of the extract.

Biochemical analysis is useful for predicting the toxicological effect of the leaf extract in animals and the safety of plant products for human
Table 2: MIC values of extract of $R$. heudolotii leaf against test organisms

\begin{tabular}{ll}
\hline Plant/microorganism & R. heudelotii MIC $(\mu \mathbf{g} / \mathbf{m L})$ \\
\hline K. pneumoniae & - \\
Shigella sp & 62.5 \\
E. coli & 31.25 \\
S. aureus & 62.5 \\
Bacillus sp. & 62.5 \\
Micrococcus sp. & 62.5 \\
S. faecali & 31.25 \\
Salmonella sp. & - \\
C. albican & - \\
\hline
\end{tabular}

K. pneumoniae: Klebsiella pneumoniae, Shigella sp.: Shigella species,

E. coli: Escherichia coli, S. aureus: Staphylococcus aureus, Bacillus sp.: Bacillus species, Micrococcus sp.: Micrococcus species, S. faecalis: Streptococcus faecalis, Salmonella sp.: Salmonella species, C. albicans: Candida albicans, R. heudelotii: Ricinodendron heudelotii, MIC: Minimum inhibitory concentration

Table 3: Effects of $\boldsymbol{R}$. heudelotii extract on organ weight after 28 days treatment

\begin{tabular}{lll}
\hline Groups & Liver (g) & Kidney (g) \\
\hline Control & $5.25 \pm 0.26$ & $0.97 \pm 0.02$ \\
$250 \mathrm{mg} / \mathrm{kg}$ & $1.03 \pm 0.04$ & $5.63 \pm 0.19$ \\
$1000 \mathrm{mg} / \mathrm{kg}$ & $5.97 \pm 0.39$ & $1.15 \pm 0.06$ \\
$500 \mathrm{mg} / \mathrm{kg}$ & $5.74 \pm 0.22$ & $1.10 \pm 0.05$ \\
$2000 \mathrm{mg} / \mathrm{kg}$ & $6.8 \pm 0.30^{*}$ & $1.20 \pm 0.37^{*}$ \\
\hline
\end{tabular}

Values represent mean \pm SEM of seven replicates. ${ }^{*} \mathrm{p}<0.05$ compared to control. R. heudelotii: Ricinodendron heudelotii, SEM: Standard error mean

Table 4: Zone of inhibition of $R$. heudelotii against bacteria and fungus isolate

\begin{tabular}{lll}
\hline Organism & \multicolumn{2}{l}{ Zone of inhibition (mm) } \\
\cline { 2 - 3 } & R. heudelotii & Gentamycin \\
\hline K. pneumo & - & 27 \\
Shigella sp & 28 & 25 \\
E. coli & 24 & 15 \\
S.aureus & 36 & 20 \\
Bacillus sp & 25 & 20 \\
Micrococcus sp & 23 & \\
S. faecali & 18 & 25 \\
Salmonella sp & - & 26 \\
C. albican & - & 15 \\
\hline
\end{tabular}

use [42]. ALP, AST, and ALT are distinct markers of hepatic injury [43]. ALT is an enzyme found in highest amount in the liver [31]. Thus, an increase of the enzyme in the blood (Fig. 1) indicates hepatic injury. This is in alignment with work done by Oyono et al. [34] when acute 
Table 5: Effects of $R$. heudelotii extract on hematological markers after 28-day treatment

\begin{tabular}{lllll}
\hline Parameters & Group A & Group B & Group C & Group D \\
\hline WBC $\left(\times 10^{12} / \mathrm{L}\right)$ & $7.13 \pm 0.26$ & $8.75 \pm 0.08$ & $9.60 \pm 0.90$ & $9.20 \pm 0.73$ \\
RBC $\left(\times 10^{12} / \mathrm{L}\right)$ & $9.22 \pm 0.34$ & $8.75 \pm 0.08$ & $9.41 \pm 0.10$ & $8.94 \pm 0.17$ \\
HGB (g/L) & $17.55 \pm 0.80$ & $17.08 \pm 0.28$ & $17.63 \pm 0.21$ & $16.88 \pm 0.43$ \\
HCT (L/L) & $54.20 \pm 1.78$ & $53.10 \pm 0.97$ & $54.88 \pm 0.25$ & $52.06 \pm 1.06$ \\
PLT (L) & $715.50 \pm 19.10$ & $590.00 \pm 14.00^{*}$ & $655.00 \pm 18.61$ & $734.67 \pm 18.22$ \\
MCV (fL) & $58.83 \pm 0.42$ & $60.73 \pm 0.96$ & $58.60 \pm 0.63$ & $58.48 \pm 0.47$ \\
MCH (pg) & $18.98 \pm 0.23$ & $19.48 \pm 0.34$ & $18.62 \pm 0.22$ & 5.00 .30 \\
MCHC (g/L) & $32.28 \pm 0.58$ & $32.13 \pm 0.26$ & $31.88 \pm 0.32$ & $19.04 \pm 0.15$ \\
LYM (\%) & $42.85 \pm 2.75$ & $34.63 \pm 0.88$ & $31.03 \pm 1.34^{*}$ & $32.60 \pm 0.17$ \\
GRAN (\%) & $35.90 \pm 3.36$ & $41.73 \pm 0.79$ & $60.77 \pm 0.71^{*}$ & $34.83 \pm 1.90$ \\
\hline
\end{tabular}

Values represent mean \pm SEM of seven replicates. ${ }^{*}$ p $<0.05$ compared with control. WBC: White blood cell count, HGB: Hemoglobin, RBC: Red blood cell count, HCT: Hematocrit, PLT: Platelet count, MCH: Mean cell hemoglobin, MCV: Mean cell volume, LYM\%: Percentage lymphocyte, MCHC: Mean corpuscular hemoglobin concentration, GRAN\%: Percentage granulocyte, R. heudelotii: Ricinodendron heudelotii

toxicity was conducted on methanolic bark extract of $R$. heudelotii. AST which is also a significant biomarker for liver disease [44] which showed a significant increase (Fig. 1). Since the liver is the major organ of detoxification and mostly exposed to different levels of ingested xenobiotics which can adversely affect hepatic cells [45]. This result suggests that the extract is likely to exert damage to liver cells at higher concentrations. The liver also helps to synthesize proteins that maintain the electrolyte balance in plasma. In line with that, $R$. heudelotii leaf extract reduced the total protein content in the groups administered 500, 100, and $2000 \mathrm{mg} / \mathrm{kg}$ b.w. of the extract. Albumin is also an important marker for liver diseases [46]. Our study showed a significant elevation of albumin in the $2000 \mathrm{mg} / \mathrm{kg}$ b.w. group.

ALP, a biomarker of liver disease and obstructive jaundice, was found to be significantly increased ( $\mathrm{p}<0.05$ ) (Fig. 1) in the $2000 \mathrm{mg} / \mathrm{kg}$ b.w. group; this suggests that the observed liver injury might be linked to biliary obstruction of the liver. This is also in line with research done by Oyono et al. [36]. This is further substantiated by a significant and steady rise in the total bilirubin (Fig. 1) concentration in the plasma caused by an obstruction in the bile duct causing an accumulation of bilirubin in the liver. Plasma urea concentration significantly increased $(p<0.05)$ at high extract doses, and this may be due to nephrotoxicity. An elevated plasma urea concentration has been associated with diseases related to nephrotoxicity since the kidney is known to dispose of waste products of metabolism [47]. During renal breakdown, there is a rise in nitrogenous substances such as urea and uric acid. However, plasma creatinine concentration was found to be insignificant.

Toxicological studies also show an increase in cholesterol concentration. High blood cholesterol concentration is one of the important possibilities during cardiovascular disease [13]. Thus, the rise in plasma total cholesterol concentration (Fig. 5) effected by the extract is harmful and may increase the risk of cardiovascular disease. This is, however, combated by a very rapid increase in the HDL-cholesterol concentration (Fig. 5) to mop up cholesterol from the blood vessels. This also shows that, at the right dose, R. heudelotii can be used in the treatment of coronary heart disease and cardiovascular diseases [48]. The toxicity exhibited by the ethanolic extract of $R$. heudelotii was reaffirmed through the histological sectioning which revealed sinusoidal congestion and severe vacuolar degeneration of hepatocytes in all treated groups. Vacuolar degeneration detected in the present study may be due to mitochondrial intermembrane space expansion and extension of the outer mitochondrial membrane [49].

\section{CONCLUSION}

The ethanol leaf extract of $R$. heudelotii may not induce significant toxic effects when administered in rats below $3600 \mathrm{mg} / \mathrm{kg}$ b.w. and thus may be safe for use as a potential candidate for the enhancement of new antimicrobial formulations as it demonstrated high antimicrobial activities. However, one should apply caution on the dosage to be administered as higher concentration could induce liver cell injury.

\section{ACKNOWLEDGMENT}

The authors are grateful to the University through the Covenant University Center for Research, Innovation and Discovery for the payment of the publication cost. We thank the support from technical staff of the Department of Biochemistry, Covenant University.

\section{REFERENCES}

1. Devadoss S, Murugaiyan I, Rajan M, Thangaraj P. Evaluation of phytochemical, antioxidnat and antimicrobial properties of ethnobotanical plant Psychotria nilgiriensis Deb. \& Gang. Int J Pharm Pharm Sci 2013;5:417-22.

2. Arhoghro EM, Ekpo KE, Anosike EO Ibeh GO. Effect of aqueous extract of bitter leaf (Vernonia amygdalina) on carbon tetrachloride $\left(\mathrm{CCl}_{4}\right)$ induced liver damage in albino Wistar rats. Eur J Sci Res 2009;26:122-30.

3. Adedosu OT, Olufemi EA, Akinola NA, Adedeji AL, Yakubu OF, Ayinde FA. Comparative antioxidants status of leaves extracts of some common antimalarial plants in West Africa. Am J Phytomed Clin Therapeut 2014;2:1480-8.

4. Clark LE, Sunderland TC. The Key NON-Timber Forest Products of Central Africa: State of the knowledge. Paper No. 122. USA: Office of Sustainable Development, Bureau for Afirca, U. S, Agency for International Development; 2004.

5. Izundu I, Nnacho N. Nutritional and A-nutritional composition of Ricinodendron heudelotii. Nat Appl Sci J 2011;12:108-16.

6. Fondoun JM, Manga TT, Kengue J. Ricinodendron heudelotii (Djansang): Ethnobotany and importance for forest dwellers in southern Cameroon. Plant Gen Resour Newsl 1999;118:1-6.

7. Momeni J, Djoulde RD, Akam MT, Kimbu SF. Chemical constituents and antibacterial activities of the stem bark extracts of Ricinodendron heudelotii (Euphorbiaceae). Indian J Pharm Sci 2005;67:386-9.

8. Abbiw D. Useful Plants of Ghana. London: Intermediate Technology Publications \& Royal Botanic Gardens Kew; 1990.

9. Burkhill HM. Useful Plants of West Tropical Africa: Families E-I. Kew, England: Royal Botanical Gardens; 1994

10. SCUC. Ndjanssang: Ricinodendron heudelotii, Field Manual for Extension Workers and Farmers. Southhampton, UK: Southhampton Center for Underutilized Crops, University of Southhampton; 2006.

11. Dhankhar S, Sharma M, Ruhil S, Balhara M, Kumar M, Chhilar A. Evaluation of antimicrobial activities of Bougainvillea spectabili. Int J Pharm Pharm Sci 2013;5:178-82

12. National Institute of Health (NIH). Guide for the Care and Use of Laboratory Animals. USA: NIH Publication; 2011. p. 85-123.

13. Adebayo AH, Aliyu R, Gatsing D, Garba IH. The effects of ethanolic leaf extract of Commiphora africana (Burseraceae) on lipid profile in rats. Int J Pharmacol 2006;2:618-22.

14. Harborne JB. Phytochemical methods: A guide to modern techniques of plant analysis. London: Chapman and Hall; 1973.

15. Sofowora A. Medicinal plants and Traditional Medicine in Africa. $2^{\text {nd }}$ ed. Ibadan: Spectrum Books Ltd; 1993.

16. Benkeblia N. Antimicrobial activity of essential oil extracts of various onions (Allium cepa) and garlic (Allium sativum). Lebenson Wiss Technol 2004;37:263-8.

17. Lorke D. A new approach to practical acute toxicity testing. Arch Toxicol 1983;54:275-87. 
18. Adebayo AH, Yakubu OF, Balogun TM. Protective properties of Citrullus lanatus on carbon tetrachloride induced liver damage in rats. Eur J Med Plants 2014a;4:979-89.

19. Weichselbaum TE. Biuret method of serum total protein estimation. Am J Clin Pathol 1946;16:40.

20. Bergmeyer HU, Hørder M, Rej R. International Federation of Clinical Chemistry (IFCC) Scientific Committee, Analytical Section: Approved recommendation (1985) on IFCC methods for the measurement of catalytic concentration of enzymes. Part 2. IFCC method for aspartate aminotransferase (L-aspartate: 2-oxoglutarate aminotransferase, EC 2.6.1.1). J Clin Chem Clin Biochem 1986;24:497-510.

21. Tietz NW, Rinker AD, Shaw LM. International Federation of Clinical Chemistry. IFCC methods for the measurement of catalytic concentration of enzymes, Part 5. IFCC method for alkaline phosphatase (orthophosphoric-monoester phosphohydrolase, alkaline optimum, EC 3.1.3.1). J Clin Chem Clin Biochem 1983;21:731-48.

22. Bergmeyer HU, Hørder M, Rej R. International Federation of Clinical Chemistry (IFCC) Scientific Committee, Analytical Section: Approved recommendation (1985) on IFCC methods for the measurement of catalytic concentration of enzymes. Part 3. IFCC method for alanine aminotransferase (L-alanine: 2-oxoglutarate aminotransferase, EC 2.6.1.2). J Clin Chem Clin Biochem 1986;24:481-95.

23. Zoppi F, Fellini D. Enzymatic colorimetric cholesterol determination. Clin Chem 1976;22:690-1.

24. Doumas BT, Watson WA, Biggs HG. Albumin standards and the measurement of serum albumin with bromcresol green. Clin Chim Acta 1971;31:87-96.

25. Doumas BT, Perry BW, Sasse EA, Straumfjord JV Jr. Standardization in bilirubin assays: Evaluation of selected methods and stability of bilirubin solutions. Clin Chem 1973;19:984-93.

26. Krieg M, Gunsser KJ, Steinhagen-Thiessen E, Becker H. Comparative quantitative clinico-chemical analysis of the characteristics of 24-hour urine and morning urine. J Clin Chem Clin Biochem 1986;24:863-9.

27. Larsen K. Creatinine assay by a reaction-kinetic principle. Clin Chim Acta 1972;41:209-17.

28. Baker FJ, Silverton RE, Pallister CJ. Baker and Silverton's Introduction to Medical Laboratory Technology. $7^{\text {th }}$ ed. Oxford: Butterworth Heinemann; 1998. p. 356-60.

29. Aliyu R, Adebayo AH, Gatsing D, Garba H. The effects of ethanolic leaf extract of Commiphora Africana (Burseraceae) on rat liver and kidney functions. J Pharmacol Toxicol 1998;2:373-9.

30. Osifo UC, Akpamu U, Idehen IC, Adisa AW, Azeke EK. The effect of chronic ingestion of crude Garcinia kola on the histology of the liver. Eur J Exp Biol 2012;2:404-9.

31. Yadav M, Chatterji S, Gupta SK, Watal G. Preliminary phytochemical screening of six medicinal plants used in traditional medicine. Int $\mathrm{J}$ Pharm Pharm Sci 2014;6:539-42.

32. Okuda T, Ito H. Tannins of constant structure in medicinal and food plants-Hydrolyzable Tannins and polyphenols related to tannins. Molecules 2011;16:2191-217.

33. Tripathy SS, Ashutosh R, Ajay M, Nibha G. Biochemical and antioxidant properties of wild edible mushrooms used for food by tribal of Eastern India. Int J Pharm Pharm Sci 2016;8:194-9.

34. Ratnam VK, Bhakshu MD, Padma Y, Venkata RR. Studies on antimicrobial and antioxidant properties of leaf extracts of Syzygium alternifolium (WT) WALP. Int J Pharm Pharm Sci 2015;7:139-43

35. Hatano T, Tsugawa MT, Ohyabu M, Kusuda S, Shiota T, Tsuchiya T, et al. Effect of polyphenols in tea and foods on methicillin-resistant Staphylococcus aureus and the sustainability of the antibacterial effects in the presence of food additives. J Jpn Soc Med Funct Foods 2006;4:43-8.

36. Oyono VA, Fokunang C, Assam JP, Voundi S, Tsafack P. Acute toxicity studies, antioxidant and in vitro antibacterial activities of extract from the barks of Ricinodendron heudolotii (Euphorbiaceae). J Pharmacogn Phytother 2014;6:47-53.

37. Clarke EG, Clarke ML. Veterinary Toxicology. London: Cassel and Collier Macmillan Publishers; 1977. p. 268-77.

38. Ashafa AO, Yakubu MT, Grierson DS, Afolayan AJ. Effects of aqueous extract from the leaves of Chrysocoma ciliata L on some biochemical parameters of Wistar rats. Afr J Biotechnol 2009;8:1425-30.

39. Ashafa AO, Sunmonu TO, Afolayan AJ. Toxicological evaluation of aqueous leaf and berry extracts of Phytolacca dioica L. in male Wistar rats. Food Chem Toxicol 2010;48:1886-9.

40. McLellan SA, McClelland DB, Walsh TS. Anaemia and red blood cell transfusion in the critically ill patient. Blood Rev 2003;17:195-208.

41. Dede EB, Igboh NM, Ayalogu OA. Chronic toxicity study of the effect of crude petroleum (Bonny light), kerosene and gasoline on rats using haematological parameters. J Appl Sci Environ Manage 2002;6:60-3.

42. Klassen CD, Eaton DL. Principles of Toxicity. In: Toxicity the Basic Science of Poisons. $4^{\text {th }}$ ed. Casaret D, editor. Pergamon: Elmsford; 1991. p. $12-50$

43. Davern TJ, Scharschmidt BF. Biochemical liver tests. In Sleisenger and Fordtran's Gastrointestinal and Liver Disease: Pathophysiology, Diagnosis, Management. $7^{\text {th }}$ ed. Feldman M, Friedman L, Sleisenger M, editors. Philadelphia, PA: Saunders; 2002. p. 1227-8.

44. Adebayo AH, Zeng GZ, Zhang YM, Fan JT, Ji CJ. Biochemical, haematological and histopathological studies of extract of Ageratum conyzoides L. In Sprague Dawley rats. J Med Plant Res 2014;4:2264-72.

45. Prosper BN, Jules KR, Modeste W, Ntiokam D. Acute and subacute toxicity studies of Zinginber officinalis roscoe essential oil on mice (swiss) and rats (wistar). Afr J Pharm Sci Pharm 2010;1:39-49.

46. Adebayo AH, Adegbite OS, Olugbuyiro JA, Famodu OO, Odenigbo KB. Toxicological evaluation of extract of Olax subsorpioidea on albino Wistar rats. Afr J Pharm Pharm 2014b;8:570-8.

47. Ogunlana OO, Ogunlana OE, Adeneye AA, Udo-Chijioke O, DareOlipede T, Olagunju JA, et al. Evaluation of the toxicological profile of the leaves and young twigs of Caesalpinia bonduc (Linn) roxb. Afr J Tradit Complement Altern Med 2013;10:504-12.

48. Omodamiro OD, Nwankwo CI. The effect of Voacanga africana leaves extract on serum lipid profile and haematological parameters on albino wistar rats. Eur J Exp Biol 2013;3:140-8.

49. Fatma F, Mortada SM, Nassar A, Soad A, Magdi A, Shin-ichi I. Antifungal activity of endophytic fungi isolated from Egyptian henbane (Hyoscyamus muticus). Pak J Bot 2010;42:2883-94. 